\title{
Accumulation and tolerance of cadmium in a non- metallicolous ecotype of Silene vulgaris Garcke (Moench)
}

\author{
Begoña Miras-Moreno ${ }^{1}$, Lorena Almagro', María Angeles Pedreño ${ }^{1}$ \& María Ángeles Ferrer ${ }^{2}$ \\ 1 Department of Plant Biology, Faculty of Biology, University of Murcia, Spain. \\ 2 Department of Agricultural Science and Technology, Universidad Politécnica de Cartagena, Cartagena, Spain.
}

Correspondence

L. Almagro

E-mail: lorena.almagro@um.es TIf.: +34637038291

Received: 13 November 2013

Accepted: 28 March 2014

Published on-line: 13 May 2014

\section{Resumen}

Acumulación y tolerancia a cadmio en un ecotipo no metalífero de Silene vulgaris Garcke (Moench)

En este estudio, se analizó el efecto de diferentes concentraciones de $\mathrm{Cd}^{2+}$ sobre un ecotipo de Silene vulgaris Garcke (Moench). La concentración de $60 \mu \mathrm{M}$ de $\mathrm{Cd}^{2+}$ provocó una ligera inhibición del crecimiento de las plantas mientras que la concentración más alta $(120 \mu \mathrm{M})$ redujo drásticamente la biomasa y la elongación de la raíz y los brotes. Además, se detectaron altos niveles de $\mathrm{Cd}^{2+}$ en las plantas, un coeficiente de bioacumulación elevado en las raíces y un bajo factor de translocación indicando que el ecotipo de $S$. vulgaris empleado en este estudio presenta una alta capacidad de acumulación de $\mathrm{Cd}^{2+}$ en las raíces y sería un buen candidato para la fitoestabilización, lo que contribuiría a reducir los niveles de $\mathrm{Cd}^{2+}$ en el suelo. Además, los resultados obtenidos indican que se debe tener precaución con el origen de esta planta, ya que podría representar una fuente adicional de $\mathrm{Cd}^{2+}$ en la dieta humana.

Palabras clave: Metal pesado, Fitoestabilización, Caryophyllaceae.

\begin{abstract}
In this study, a pot experiment was developed using a non-metallicolous ecotype of Silene vulgaris Garcke (Moench) exposed to 0, 60 and $120 \mu \mathrm{M} \mathrm{Cd}^{2+}$ for 13 days. The dose of $60 \mu \mathrm{M} \mathrm{Cd}^{2+}$ had little effect on the growth of $S$. vulgaris plants, whereas the highest dose produced a drastic reduction in biomass, and root and shoot elongation. The high internal $\mathrm{Cd}^{2+}$ concentration together with the high bioaccumulation coefficient in roots and the low translocation factor indicated that this ecotype could be a good candidate for the phytostabilisation of $\mathrm{Cd}^{2+}$-contaminated soils. In view of the widespread use of this plant in popular medicine and the cuisine of Mediterranean countries, the results obtained also suggest that caution needs to be taken concerning its origin since it could represent an additional source of $\mathrm{Cd}^{2+}$ in the human diet.
\end{abstract}

Key words: Heavy metal, Phytostabilisation, Caryophyllaceae. 


\section{Introduction}

Cadmium $\left(\mathrm{Cd}^{2+}\right)$ is a widespread, highly toxic heavy metal that enters the environment mainly from industrial processes and fertilisers, resulting in the pollution of water, air and soil (Gallego et al. 2012). Several human disorders have been attributed to the ingestion of $\mathrm{Cd}$, including learning disabilities in children (Marlowe et al. 1985), neurological disorders (Chen et al. 2011), the impairment of bone metabolism and increased cancer rates (Järup \& Akesson 2009).

Cultivated and wild edible plants are the main source of heavy metal intake in humans (McLaughlin et al. 1999, Clemens 2006). In fact, the young shoots and tender leaves of Silene vulgaris, which is a perennial herb belonging to the Caryophyllaceae, are widely consumed as vegetables in many Mediterranean countries (Conforti et al. 2011, Cakilcioglu et al. 2011). S. vulgaris plants are also used in traditional and folk medicine as antianemic (Conforti et al. 2011) and anti-inflammatory (Cakilcioglu et al. 2011) agents. Moreover, these plants are an interesting source of polysaccharides -silenan- that exhibit macrophage immunomodulatory properties (Popov et al. 1999).

On the other hand, the occurrence of plants on naturally metal-enriched soils indicates that these plant species have evolved to develop metal resistance mechanisms under several environmental conditions (Ernst et al. 2000; Martínez-Iñigo et al. 2009). Silene vulgaris Garcke (Moench) is a facultative metallophyte that shows multiple tolerance and co-tolerance to heavy metals (Ernst et al. 2000). In fact, several authors have reported the effectiveness of some metallicolous ecotypes of $S$. vulgaris in the revegetation of contaminated soils (Mohtadi et al. 2012, Pérez-Sanz et al. 2012). Taking into account the traditional uses of $S$. vulgaris and its pharmaceutical potential, it is therefore of considerable interest to understand how nonmetallicolous ecotypes of $S$. vulgaris, which are not genetically adapted to grow on metal-enriched soils, incorporate and accumulate heavy metals. Consequently, in this work, the effect of different concentrations of $\mathrm{Cd}^{2+}$ on biomass production, plant growth and yield, as well as the distribution of $\mathrm{Cd}^{2+}$ in roots and leaves in a non-metallicolous ecotype was studied.

\section{Materials and methods}

\section{Plant material}

The seeds used in this study were provided by the germplasm bank of the Universidad Politécnica de Cartagena, registered as accession UPCT-01-313. The seeds were collected from a non-polluted soil of Cartagena ( $\left.37^{\circ} 41^{\prime} 50^{\prime}{ }^{\prime} \mathrm{N}, 1^{\circ} 0.5^{\prime} 05^{\prime \prime} \mathrm{W}\right)$ in where $\mathrm{Cd}$ levels are assumed to be relatively low. S. vulgaris seeds were surface-sterilised for $2 \mathrm{~min}$ in $70 \%$ ethanol, transferred to $10 \% \mathrm{NaOCl}$ for 10 min, rinsed three times with sterile distilled water, and placed on $150 \times 25 \mathrm{~mm}$ Petri dishes containing filter paper moistened with distilled $\mathrm{H}_{2} \mathrm{O}$. The Petri dishes were incubated in the dark at $25{ }^{\circ} \mathrm{C}$ for $72 \mathrm{~h}$. Then, the seed germination rate was scored, and seedlings were transplanted into vermiculite in polyethylene containers $(15 \times 15 \times 20$ $\mathrm{cm}$, one plant per pot) and grown under a $16 \mathrm{~h}$ photoperiod with $24 / 22{ }^{\circ} \mathrm{C}$ day/night temperature, with a photon flux density of $120 \mu$ mol photons $\mathrm{m}^{-2} \mathrm{~s}^{-1}$, and $65 \%$ relative humidity. The seedlings were watered with one-quarter-strength Hoagland solution (Sigma-Aldrich, Spain), adjusted to $\mathrm{pH}$ 6.0, for 1 week and then, full strength medium for another week. Seventeen-day-old plants of uniform height and number of leaves were used in the $\mathrm{Cd}^{2+}$ treatments.

\section{Cadmium treatments}

Moderate levels of $\mathrm{Cd}^{2+}$ pollution in soil solutions have a $\mathrm{Cd}^{2+}$ concentration range of between 0.32 and $1 \mu \mathrm{M}$ (Sanità di Toppi \& Gabbrielli 1999), and so to induce an acute $\mathrm{Cd}^{2+}$ stress, doses of 60 and $120 \mu \mathrm{M} \mathrm{Cd}^{2+}$ were chosen. Seventeen-day-old plants were split into in four groups and the assay was started by the addition of 60 or $120 \mu \mathrm{M} \mathrm{Cd}^{2+}$ (in the form of $\mathrm{Cd}\left(\mathrm{NO}_{3}\right)_{2} .4 \mathrm{H}_{2} \mathrm{O}$; Sigma-Aldrich, Spain) for the $\mathrm{Cd}^{2+}$ treatments. As control, plants were watered with 120 and $240 \mu \mathrm{M} \mathrm{KNO}_{3}$.

\section{Growth and biomass determinations}

Plant growth was measured by an assessment of shoot height, root length, fresh weight and the oven-dry weight $\left(60^{\circ} \mathrm{C}, 24 \mathrm{~h}\right)$ of roots and leaves. Root length was determined as the distance between the root-shoot junction and the tip of the main root. Plants were harvested after 13 days of $\mathrm{Cd}^{2+}$ exposure. 


\section{Cadmium determination}

The roots of the $\mathrm{Cd}^{2+}$-treated plants were immersed in $2 \mathrm{mM} \mathrm{Na}_{2}$ EDTA for $15 \mathrm{~min}$ to remove $\mathrm{Cd}^{2+}$ adhered to the root surface (Liu et al. 2009) and then the roots, stems and leaves were separated. Dried samples were ashed in a muffle furnace (Select-Horn furnace P-Selecta) at $450{ }^{\circ} \mathrm{C}$ for $8 \mathrm{~h}$. The ashes were digested with an acid oxidative mixture $\mathrm{H}_{2} \mathrm{O}: \mathrm{HNO}_{3}(65 \%): \mathrm{H}_{2} \mathrm{O}_{2}(30 \%)(3: 2: 5$, $\mathrm{v} / \mathrm{v} / \mathrm{v})$. The concentration of $\mathrm{Cd}^{2+}$ in the samples was determined by Inductively Coupled Plasma Emission Spectroscopy (ICP, Agilent 7500CE).

\section{Determination of the Tolerance Index, Bio- accumulation Coefficient and Translocation Factor}

The Tolerance Index (TI) at different individual concentrations of $\mathrm{Cd}^{2+}$ was calculated by dividing the root length at the different metal concentrations by that obtained in the control treatments (Wilkins 1978), using the following equation: TI $(\%)=100 \times$ (root length in metal treatment) $/$ (root length in the control). The Bioaccumulation Coefficient (BAC) was calculated according to the formula: $\mathrm{BAC}=$ metal concentration $\left(\mu \mathrm{g} \mathrm{g} \mathrm{g}^{-1}\right.$ dry weight) in leaves or roots/metal concentration ( $\mu \mathrm{g}$ $\mathrm{ml}^{-1}$ ) in nutrient solution. The Translocation Factor (TF), which indicates the ability of plants to translocate heavy metals from the roots to the shoots (Liu et al. 2009), was calculated as the relation between metal concentration in leaves and metal concentration in roots.

\section{Statistical analysis}

Data were analysed by one-way analysis of variance (ANOVA) followed by Tukey's HSD test in order to examine the significance of the observed differences using the SPSS package (SPSS Inc., Chicago, USA) version 19.0, and $\mathrm{P}$ values $<0.05$ were considered as statistically significant.

\section{Results}

\section{Growth and metal tolerance in S. vulgaris plants}

When $S$. vulgaris plants were treated with $\mathrm{Cd}^{2+}$, all the growth parameters analysed (shoot and root size, fresh and dry weights of leaves and roots) decreased significantly as $\mathrm{Cd}^{2+}$ concentration increased compared to controls (Table 1). The adverse effects of $\mathrm{Cd}^{2+}$ were more pronounced on shoot growth than on root growth. Thus, when $120 \mu \mathrm{M} \mathrm{Cd}^{2+}$ was added to the medium, $79 \%$ reduction in leaf fresh weight and $60 \%$ reduction in root fresh biomass were observed. Root and shoot elongations were also reduced by $50 \%$ and $56 \%$, respectively (Table 1). Moreover, at this concentration, browning of the root-tips and chlorosis, which are specifically symptoms of $\mathrm{Cd}^{2+}$ toxicity, were observed (data not shown). In contrast, the dose of $60 \mu \mathrm{M} \mathrm{Cd}^{2+}$ had little effect on the growth of $S$. vulgaris plants, and the plants showed no visual phytotoxic symptoms. The TI, based on root length for the different $\mathrm{Cd}^{2+}$ doses, indicated

\begin{tabular}{lccc}
\hline \multirow{2}{*}{ Parameter } & \multicolumn{3}{c}{$\mathbf{C d}^{2+}$ concentration in the medium } \\
\cline { 2 - 4 } & $\mathbf{0} \boldsymbol{\mu} \mathbf{M}$ & $\mathbf{6 0} \boldsymbol{\mu} \mathbf{M}$ & $\mathbf{1 2 0} \boldsymbol{\mu M}$ \\
\hline Root elongation (mm) & $16 \pm 2^{\mathrm{a}}$ & $14 \pm 3^{\mathrm{a}}(12.5 \%)$ & $8 \pm 1^{\mathrm{b}}(50 \%)$ \\
Shoot elongation (mm) & $91 \pm 7^{\mathrm{a}}$ & $80 \pm 6^{\mathrm{a}}(12 \%)$ & $40 \pm 5^{\mathrm{b}}(56 \%)$ \\
Root fresh weight (mg/plant) & $100 \pm 8^{\mathrm{a}}$ & $72 \pm 7^{\mathrm{b}}(28 \%)$ & $40 \pm 4^{\mathrm{c}}(60 \%)$ \\
Root dry weight (mg/plant) & $10.2 \pm 0.8^{\mathrm{a}}$ & $7.0 \pm 0.6^{\mathrm{b}}(30 \%)$ & $4.1 \pm 0.4^{\mathrm{c}}(60 \%)$ \\
Leaf fresh weight (mg/plant) & $560 \pm 54^{\mathrm{a}}$ & $380 \pm 25^{\mathrm{b}}(32 \%)$ & $120 \pm 6^{\mathrm{c}}(79 \%)$ \\
Leaf dry weight (mg/plant) & $62.0 \pm 3.2^{\mathrm{a}}$ & $44.3 \pm 1.7^{\mathrm{b}}(29 \%)$ & $20.2 \pm 1.1^{\mathrm{c}}(68 \%)$ \\
TI & & $88 \%$ & $47 \%$ \\
\hline
\end{tabular}

Data are means of $n=10( \pm$ SE). Different letters indicate significant differences at $p<0.05$ according to the Tukey HSD test

Tabla 1. Tamaño de raíz y brote, masa e índice de tolerancia de plantas de Silene vulgaris expuestas a 0,60 y $120 \mu \mathrm{M}$ de Cd ${ }^{2+}$. Las plantas se recolectaron después de 13 días de tratamiento. Los valores entre paréntesis representan el porcentaje de inhibición respecto a los grupos control.

Table 1. Root and shoot size, mass and tolerance index of Silene vulgaris plants exposed to 0,60 , and $120 \mu \mathrm{M} \mathrm{Cd}{ }^{2+}$. Plants were collected after 13 days of treatment. Values in brackets are \% inhibition from their respective control groups 
that $S$. vulgaris could tolerate a relative excess of $\mathrm{Cd}^{2+}(60 \mu \mathrm{M}$, TI $>85 \%)$ but was more sensitive to the dose of $120 \mu \mathrm{M}(\mathrm{TI}<50 \%)$ (Table 1$)$.

\section{Concentration and accumulation of $\mathrm{Cd}^{2+}$ in root and leaves of $S$. vulgaris plants}

The $\mathrm{Cd}^{2+}$ concentration in S. vulgaris tissues increased significantly in both leaves and roots as $\mathrm{Cd}^{2+}$ concentration in the medium increased (Table 2). However, most of the $\mathrm{Cd}^{2+}$ absorbed by the plants was found in the root tissues. In fact, when plants were exposed to 60 and $120 \mu \mathrm{M} \mathrm{Cd}^{2+}$, the concentration of accumulated $\mathrm{Cd}^{2+}$ in root tissues was $203.3 \pm 17.8$ and $750.4 \pm 9.2 \mu \mathrm{g} \mathrm{g}^{-1}$ dry weight, respectively, while the concentration in leaves was $7.0 \pm 0.9$ and $19.1 \pm 1.3 \mu \mathrm{g} \mathrm{g}^{-1}$ dry weight, respectively. In addition, in S. vulgaris roots, BACs were 12.43 and 20.27, with 60 and $120 \mu \mathrm{M} \mathrm{Cd}^{2+}$, respectively, while BACs in leaves were in the range of $0.38-0.51$, in the presence of 60 and $120 \mu \mathrm{M} \mathrm{Cd}^{2+}$, respectively. Moreover, the tendency to translocate $\mathrm{Cd}$ from the roots to the leaves, as estimated by TF, was of 0.034 and 0.025 in the presence of 60 and $120 \mu \mathrm{M} \mathrm{Cd}^{2+}$, respectively (Table 2 ).

\section{Discussion}

In this work, a non-metallicolous ecotype of $S$. vulgaris was used to assess the effects of different concentrations of $\mathrm{Cd}^{2+}$ on its growth, TI, metal uptake and accumulation. It is well established that both growth inhibition and a reduction of biomass production are part of a generic stress-induced morphogenic response that allow plants to decrease stress exposure (Potters et al. 2007). Furthermore, the most commonly used method for monitoring $\mathrm{Cd}^{2+}$ toxicity is based on root elongation (Prasad 1995). In the present study, leaf biomass was more sensitive to $\mathrm{Cd}^{2+}$ than other measured growth parameters, including root and shoot lengths. The decrease in leaf biomass observed in $S$. vulgaris plants under acute $\mathrm{Cd}^{2+}$ stress can be explained, at least in part, by the direct effects of $\mathrm{Cd}^{2+}$ on the inhibition of both cell elongation and division rates (Prasad 1995, Sanità di Toppi \& Gabbrielli 1999, Fusconi et al. 2006). Nevertheless, since $\mathrm{Cd}^{2+}$ also interferes with several physiological processes, such as photosynthesis, plant water status, and mineral nutrition (Prasad 1995, Gallego et al. 2012), an effect on leaf biomass production could not be excluded.

Despite the fact that a non-metallicolous ecotype of $S$. vulgaris was used, this ecotype can be considered as tolerant to relatively high $\mathrm{Cd}^{2+}$ concentrations, as shown by its TI values. Several authors (De Knecht et al. 1994, Schat et al. 2000) evaluated $\mathrm{Cd}^{2+}$ tolerance in non-metallicolous and metallicolous populations of $S$. vulgaris, and reported that both $\mathrm{Cd}^{2+}$-imposed root growth inhibition (Schat et al. 2000) and $\mathrm{Cd}^{2+}$ accumulation in root tips (De Knecht et al. 1994) were similar in both populations of $S$. vulgaris. In this study, the internal $\mathrm{Cd}^{2+}$ concentration in roots was much higher than that found in leaves, and increased as the external $\mathrm{Cd}^{2+}$ levels increased. These results agree with previous investigations reporting that there is normally more $\mathrm{Cd}^{2+}$ in roots than in leaves (Clemens 2006, and references herein). The accumulated $\mathrm{Cd}^{2+}$ in root tissues was several times above the threshold values found in shoots of $\mathrm{Cd}^{2+}$-hyperaccumulator plants $\left(100 \mu \mathrm{g} \mathrm{Cd} \mathrm{g^{-1 }}\right.$ dry weight) (Maestri et al. 2010).

In addition, in order to qualify the heavy metal accumulation efficiency in $S$. vulgaris plants, the BAC or phytoextraction rate, must be taken into consideration. On the basis of BAC, plants can be classified into four groups according to their capacity to accumulate heavy metal: "non-accumulator", species or plant part with $\mathrm{BAC}<0.01$;

\begin{tabular}{cccccc}
\hline $\begin{array}{c}\mathbf{C d}^{2+} \text { concentration } \\
\text { in the medium }\end{array}$ & \multicolumn{2}{c}{$\begin{array}{c}\mathbf{C d}^{2+} \text { concentration in plant tissues } \\
\left(\boldsymbol{\mu g} \mathbf{~ g}^{-1} \text { Dry Weight) }\right.\end{array}$} & \multicolumn{2}{c}{ BAC } & TF \\
\cline { 2 - 6 } & \multicolumn{2}{c}{ Leaves } & Roots & Leaves & Roots \\
\hline $0 \mu \mathrm{M}$ & nd & nd & & \\
$60 \mu \mathrm{M}$ & $7.0 \pm \pm 0.9$ & $203.3 \pm 17.8$ & 0.38 & 12.43 & 0.034 \\
$120 \mu \mathrm{M}$ & $19.1 \pm 1.3$ & $750.4 \pm 9.2$ & 0.51 & 20.27 & 0.025 \\
\hline
\end{tabular}

nd, not detected. Data are means of $n=3( \pm S E)$

Tabla 2. Concentración de $\mathrm{Cd}^{+2}$, Coeficiente de Bioacumulación (BAC) y Factor de Translocación (TF) en hojas y raíces de plantas de Silene vulgaris tratadas con 0,60 y $120 \mu \mathrm{M} \mathrm{Cd}^{2+}$ durante 13 días.

Table 2. Concentration of $\mathrm{Cd} 2+$, Bioaccumulation Coefficient (BAC), and Translocation Factor (TF) in leaves and roots of Silene vulgaris plants treated with 0,60 and $120 \mu \mathrm{M} \mathrm{Cd}^{2+}$ for 13 days. 
"low accumulator", with BAC values between 0.01-0.1; "moderate accumulator", 0.1-1.0; and "hyperaccumulator", BAC >1 (Sekabira et al. 2011). In $S$. vulgaris roots, BACs were always higher than 1. However, the tendency to translocate $\mathrm{Cd}^{2+}$ from the roots to the leaves, as estimated by $\mathrm{TF}$, was low. Nevertheless, BACs in leaves were in the range of $0.38-0.51$, indicating that this plant had a good potential for accumulating $\mathrm{Cd}^{2+}$ in leaf tissues. Plants that over-accumulate heavy metals in their roots, excluding or limiting translocation to shoots, can be regarded as efficient to phytostabilise heavy metals in soils (MacGrath \& Zhao 2003, Maestri et al. 2010). Thus, this species could be used for phytostabilisation of soils with low $\mathrm{Cd}^{2+}$ bioavailability, to avoid high accumulation in leaves.

On the other hand, given the continued accumulation of $\mathrm{Cd}^{2+}$ in many fertilized agricultural soils (McLaughlin et al. 1999, Bhat et al. 2010), and taking into account the ethnobotanical relevance of this species in Mediterranean countries, the results obtained suggest that caution has to be taken about its use, since it could represent an additional source of $\mathrm{Cd}$ in the human diet whose maximum levels allowed are $7 \mu \mathrm{g} \mathrm{kg}^{-1}$ human body weight.

In conclusion, based on its good growth, its TI, $\mathrm{BAC}$ and $\mathrm{TF}$ under acute $\mathrm{Cd} 2+$ stress, these results suggest that this non-metallicolous ecotype of $\mathrm{S}$. vulgaris has a high tolerance towards $\mathrm{Cd}^{2+}$. The high internal $\mathrm{Cd}^{2+}$ concentration, the high $\mathrm{BAC}$ in roots, and the low TF indicate that this plant could be a good candidate for phytostabilisation of $\mathrm{Cd}^{2+}$-contaminated soils

\section{Acknowledgements}

We thank Dr. Juan J. Martínez (UPCT) for kindly providing $S$. vulgaris seeds.

\section{References}

Bhat RK., Arun AB \& Karim AA. 2010. Determination of Mineral Composition and Heavy Metal Content of Some Nutraceutically Valued Plant Products. Food analytical methods 3: 181-187.

Cakilcioglu US, Khatun I, Turkoglu I \& Hayta S. 2011. Ethnopharmacological survey of medicinal plants in Maden (Elazig-Turkey). Journal of Ethnopharmacology 137: 469-486.

Clemens S. 2006. Toxic metal accumulation, responses to exposure and mechanisms of tolerance in plants Biochimie 88: 1707-1719

Conforti F, Marrelli M, Carmela C, Menichini F, Valentina P, Uzunov D, Statti GA, Duez P \& Menichini F. 2011. Bioactive phytonutrients (omega fatty acids, tocopherols, polyphenols), in vitro inhibition of nitric oxide production and free radical scavenging activity of non-cultivated Mediterranean vegetables. Food Chemistry 129: 1413-1419.

Chen L, Xu B, Liu L, Luo Y, Zhou H, Chen W, Shen T, Han X, Kontos CD \& Huang S. 2011. Cadmium induction of reactive oxygen species activates the mTOR pathway, leading to neuronal cell death. Free Radical Biology and Medicine 50: 624-632.

De Knecht JA, Van Dillen M, Koevoets PLM, Schat H, Verkleij JAC \& Ernst WHO. 1994. Phytochelatins in cadmium sensitive and cadmium tolerant Silene vulgaris. Chain length distribution and sulphide incorporation. Plant Physiology 104: 255-261.

Ernst WHO \& Nelissen HJM. 2000. Life-cycle phases of a zinc- and cadmium-resistant ecotype of Silene vulgaris in risk assessment of polymetallic mine soils. Environmental Pollution 107: 329-338.

Ernst WHO. 2006. Evolution of metal tolerance in higher plants. Forest Snow and Landscape Research 80: 251-274.

Fusconi A, Repetto O, Bona E, Massa N, Gallo C, Dumas-Gaudot E \& Berta G. 2006. Effects of cadmium on meristem activity and nucleus ploidy in roots of Pisum sativum L. CV. Frisson seedlings. Environmental and Experimental Botany 58: 253-260.

Gallego SM, Pena LB, Barcia RA, Azpilicueta CE, Iannone MF \& Rosales EP. 2012. Unravelling cadmium toxicity and tolerance in plants: insight into regulatory mechanisms. Environmental and Experimental Botany 83: 33-46

Järup L \& Åkesson A. 2009. Current status of cadmium as an environmental health problem. Toxicology and Applied Pharmacology 238: 201-208.

Liu Z, He X, Chen W, Yuan F, Yan K \& Tao D. 2009. Accumulation and tolerance characteristics of cadmium in a potential hyperaccumulator - Lonicera japonica Thunb. Journal of Hazardous Materials 2: 170-175.

MacGrath SP \& Zhao FJ. 2003. Phytoextraction of metal and metalloids form contaminated soils. Current Opinion in Biotechnology 14: 277-282.

Maestri E, Marmiroli M, Visioli G \& Marmiroli N. 2010. Metal tolerance and hyperaccumulation: Costs and trade-offs between traits and environment. Environmental and Experimental Botany 68: 1-13.

Marlowe M, Cossairt A, Moon C, Errera J, MacNeel A, Peak R, Ray J \& Schroeder C. 1985. Main and interaction effects of metallic toxins on classroom behavior. The Journal of Abnormal Child Psychology 13: 185-198.

Martínez-Iñigo MJ., Pérez-Sanz A., Ortiz I., Alonso J., Alarcón R., García P \& Lobo MC. 2009. Bulk soil and rhizosphere bacterial community PCR-DGGE profiles and $\beta$-galactosidase activity as indicators of biological quality in soils contaminated by heavy metals and cultivated with Silene vulgaris (Moench) Garcke. Chemosphere 75: 1376-1381. 
McLaughlin MJ, Parker DR \& Clarke JM. 1999. Metals and micronutrients - food safety issues. Field Crops Research 60: 143-163.

Mohtadi A, Ghaderian SM \& Schat H. 2012. A comparison of lead accumulation and tolerance among heavy metal hyperaccumulating and non-hyperaccumulating metallophytes. Plant and Soil 352: 267276.

Pérez-Sanz A, Millán R, Sierra MJ, Alarcón R, García P, Gil-Díaz M, Vazquez S \& Lobo MC. 2012. Mercury uptake by Silene vulgaris grown on contaminated spiked soils. Journal of Environmental Management 95: 233-237.

Popov SV, Popova GY, Ovodova RG, Bushneva OA \& Ovodov YS. 1999. Effects of polysaccharides from Silene vulgaris on phagocytes. International Immunopharmacology 21: 617-624.

Potters G, Pasternak TP, Guisez Y, Palme KJ \& Jansen MAK. 2007. Stress-induced morphogenic responses: growing out of trouble?. Trends in Plant Science 12: 98-105.
Prasad MNV. 1995. Cadmium toxicity and tolerance in vascular plants. Environmental and Experimental Botany 35: 525-545.

Sanità di Toppi L \& Gabbrielli R. 1999. Response to cadmium in higher plants. Environmental and Experimental Botany 41: 105-130.

Schat H, Llugany M \& Bernhard R. 2000. Metal-specific patterns of tolerante, uptake and transport of heavy metals in hyperaccumulating and non-hyperaccumulating metallophytes. In Phytoremediation of contaminated soil and water (Lewis Publishers, eds), pp: 178-195.

Sekabira K, Oryem-Origa H, Mutumba G, Kakudidi E \& Basamba TA. 2011. Heavy metal phytoremediation by Commelina benghalensis (L) and Cynodon dactylon (L) growing in urban stream sediments. International Journal of Plant Physiology and Biochemistry $3: 133-142$.

Wilkins DA. 1978. The measurement of tolerance to edaphic factors by means of root growth. New Phytologist 80: 623-633. 